\title{
Study on Countermeasures to Improve the Cultural Confidence of Young College Students
}

\author{
Chuansheng Song \\ Yancheng Teachers University, Yancheng, China \\ Email:659508358@qq.com
}

How to cite this paper: Song, C.S. (2019) Study on Countermeasures to Improve the Cultural Confidence of Young College Students e. Open Journal of Social Sciences, 7, 347-351.

https://doi.org/10.4236/jss.2019.712026

Received: December 10, 2019

Accepted: December 23, 2019

Published: December 26, 2019

Copyright (c) 2019 by author(s) and Scientific Research Publishing Inc. This work is licensed under the Creative Commons Attribution International License (CC BY 4.0).

http://creativecommons.org/licenses/by/4.0/

\begin{abstract}
The cultural self-confidence of young college students is an important part of cultural self-confidence. So it is urgent to improve the cultural self-confidence of young college students, should stick to the Chinese culture position, based on the reality in contemporary China, combined with the contemporary conditions. Under the guidance of Xi Jinping Thought on Socialism with Chinese Characteristics for a New era, we adopt the following strategies to enhance the cultural confidence of young college students, firmly grasp the ideological work leadership, adhere to the cultivation and practice of socialist core values, improve ideological and political work in colleges and universities.
\end{abstract}

\section{Keywords}

Young College Students, Cultural Confidence, Countermeasures

\section{Introduction}

Young college students are important participants, witnesses and strivers in the course of the realization of the great rejuvenation of the Chinese nation. Young college students are the main force to inherit, develop and innovate the culture. Their cultural confidence directly affects the realization of cultural power and the realization of the goal of socialist modernization. In the new era, it is necessary for young college students to become builders and successors of the socialist cause with all-round development of morality, intelligence, physique, beauty and labor. The cultural self-confidence of young college students is not only a simple cultural identity, but also a way to internalize the culture into their own accomplishment on the basis of cultural identity, which is manifested in their own practical actions and shows their national culture with a highly confident attitude. At present, promoting the cultural self-confidence of young college students is the emphasis of ideological and political work in colleges and universi- 
ties, as well as the due meaning required by the new era.

\section{Following the Fundamental to Promote the Cultural Self-Confidence of Young College Students}

1) Stick to Chinese culture

Stand firm on Chinese culture. First, we must adhere to the guidance of Marxism. Marxism is the compass of social undertakings with Chinese characteristics. The combination of Marxism and China's concrete practice produces the latest theoretical achievements of Sinicization of Marxism. Some college students only study Marxist theory from the perspective of exam-oriented, without systematic cognition and understanding of Marxist theory and the latest theoretical achievements of Marxism in China [1]. In the new era, young students must consciously take Marxism as a guide, and use the viewpoints and methods contained in Xi jinping Thought on Socialism with Chinese Characteristics for a New Era to solve practical problems in their study and life, so as to realize the mastery of learning, thinking and application of new thoughts. Knowledge, faith, unity. Second, the socialist culture with Chinese characteristics is deeply rooted in the excellent traditional culture and great practice, and thus has Chinese characteristics, Chinese style. To stand firm on Chinese culture is the expression of firm cultural confidence. Young college students should have a deep understanding of their own culture and develop the Chinese culture through innovation.

2) Base on the reality of contemporary China

Based on the reality of contemporary China, the key is to have a deep understanding that the new era is an era of decisive victory in completing the building of a moderately prosperous society in all respects and the building of a great modern socialist country in all respects. First of all, we must be fully aware that although China is getting closer and closer to our goal, we must not be blindly optimistic. We must maintain a calm and stable attitude and constantly remind ourselves that China's development still lags far behind the goal of becoming a world power. Secondly, we must clearly see that although the Chinese culture has been continuously inherited for five thousand years, the impact of various forces on the Chinese culture is huge, leading to the lack of cultural confidence of some Chinese people. Finally, with a high sense of mission and responsibility, college students should strive to develop and innovate the advanced socialist culture, meet people's higher requirements for spiritual and cultural life, and explain to the world the "developing, open and seeking greater common ground for the world" based on the reality of contemporary China [2].

3) Combining the Conditions of the Current Era

The combination of the conditions of the current era requires young college students to grasp the characteristics of The Times and the law and trend of cultural development, so that cultural confidence always reflects the requirements of The Times and reflects the spirit of The Times. Firstly, we should introduce 
the excellent cultural achievements of other countries and nations, adopt the attitude of learning from them and actively absorb the beneficial elements. Secondly, we must deeply realize that during the period of great changes at home and abroad, China's ideological field is facing a severe and complex situation. Some western countries try to overthrow the leadership of the communist party and the socialist system through cultural invasion. Western culture enters China wrapped in "sugar coating" and tries to attract college students to use for it, thus reaching a plot to disrupt the society and overthrow the regime. Thirdly, the main way for today's college students to get information is the Internet. The network information is complicated, and the good and bad are intermingled. College students should improve their ability to identify and select information, and be highly alert to foreign cultures.

\section{Strategies to Enhance the Cultural Confidence of Young College Students}

1) Under the guidance of Xi Jinping Thought on Socialism with Chinese Characteristics for a New Era, mastering the leadership of ideological work

The leadership and initiative of ideological work are the basis of cultural self-confidence promotion of young college students. We must firmly grasp: first, strengthen the leadership of the parties and equip students with Xi Jinping Thought on Socialism with Chinese Characteristics for a New Era. Ideological and political course is the main channel to improve students' theoretical level, cultivate students' cultural confidence and master ideological work. Through the reform and innovation of ideological and political courses, colleges and universities can make ideological and political courses better, and make great efforts in times, appeal and attraction, so as to truly respond to students' concerns and solve their doubts. Second, the faculty should be optimized. College teachers should have the consciousness of bearing mission, and strive to improve their political quality and professional practice ability, improve students' deep understanding of the importance of cultural self-confidence. In a way that students are happy to see, Xi Jinping thought on socialism with Chinese characteristics for a new era can penetrate into students' hearts, so that students can truly understand the connotation, content and requirements of cultural confidence. Thirdly, the collaborative education mechanism should be constructed. The improvement of students' cultural confidence is not a task that can be completed by a single department. It requires all departments to cooperate with each other, adhere to the principle of joint efforts to educate people, and achieve the effect of educating people. Finally, we should use Internet technology to consolidate the main position of network ideology. Internet technology is increasingly mature, the rapid popularization of network mobile media terminals, by the young people's favor and love. In order to prevent the corruption of the minds of young college students by the content of yellow culture, violence culture, religious culture and anti-socialist culture, colleges and universities must seize the 
main battlefield of the Internet, firmly grasp the ideology of students and enhance their cultural confidence.

2) Adhere to the cultivation and practice of core socialist values, and take multiple measures to enhance the self-confidence and effectiveness of youth culture confidence

To enhance the cultural confidence of young college students must be closely combined with the cultivation and practice of socialist core values of college students. First, colleges and universities should transform core values into students' daily lifestyle and students' conscious pursuit, so as to realize students' cognitive identity, emotional identity and behavioral identity. Through various practical activities, colleges and universities can make the core socialist values integrate into students' study and life by means of visual interpretation, story expression and popularization. At the same time, the combination of explicit positive publicity education and implicit imperceptible education can change indoctrination education into active learning and forced implementation into active practice. The second is to carry forward the advanced model function. By inviting outstanding social figures, outstanding alumni and advanced representatives of college students to make regular reports and exchanges for young college students, we can give play to their demonstration power and appeal power, so as to infect young college students with excellent power and improve their cultural confidence. At the same time, college teachers should set an example for students with their own exemplary behavior and noble ethics. Third, build a Shared platform for cultivating socialist core values among colleges and universities. Colleges and universities should strengthen cooperation and communication, release information and cases on the Shared platform, optimize the allocation of educational resources, and guide students to cultivate and practice socialist core values. Fourth, the creative transformation and innovative development of the fine traditional Chinese culture. Through innovation and development of traditional culture, we should dig deep into the ideological concepts, moral standards and humanistic spirit contained in it and turn them into the Chinese spirit and strength in the new era.

3) Rely on the innovative development of ideological and political work in colleges and universities, and explore multiple channels to enhance the cohesion of youth cultural confidence

The cultural self-confidence of young college students should be integrated into the innovative development of ideological and political work in colleges and universities, constantly improve the long-term mechanism of promoting the cultural self-confidence of young students, and explore the convergence of enhancing the cultural self-confidence of students in multiple dimensions. First, the education of ideals and beliefs. Guide the students to set up the communist ideal. We firmly believe that the ideal of communism is an ideal that will be realized through hard work. To guide students to establish the common ideal of socialism with Chinese characteristics, to firmly trust the party, to firmly obey the 
leadership of the party, and to safeguard the authority of the party central committee. In personal thought and action with the party central committee to maintain a high degree of consistency. The second is to carry out moral cultivation projects. Guide young people to show great virtue, abide by public morality and be strict with private moral. We should guide students to make contributions to the nation, and encourage them to start from small things, so as to train them to be moral people meeting the needs of social development. Third, universal general education. Colleges and universities should intensify curriculum reform and popularize general education courses. We can help students understand the party and the country's latest major policies and major decisions; Carrying forward the scientific spirit is conducive to the popularization and crossover of various scientific and cultural knowledge and expand students' knowledge accomplishment. Break the limit of specialty, strengthen the humanistic quality, and realize the all-round development of college students. Finally, pay attention to the construction of campus culture. Through the implementation of, social practice, class activities, etc., we will inherit and carry forward the excellent traditional culture and revolutionary spirit of China; through the construction of system culture, we will give full play to the positive role of university spirit, cultivate excellent school spirit, teaching style and learning style, and improve the cultural self-confidence of young college students.

\section{Conflicts of Interest}

The author declares no conflicts of interest regarding the publication of this paper.

\section{References}

[1] Zeng, Q.M. (2017) Realization Path of Cultural Confidence: Probe into Xi Jinping's Cultural Confidence View. Research on Socialism, No. 4, 7-14.

[2] Song, C.S. (2019) Cultural Self-Confidence Cultivation of Young College Students in the New Era. School Party Building and Ideological Education, No. 5, 53. 